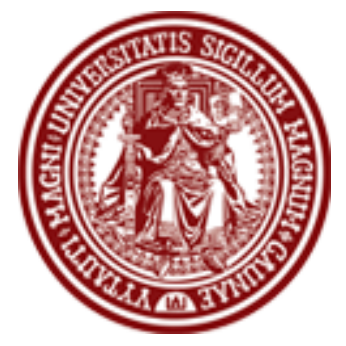

BALTIC JOURNAL OF LAW \& POLITICS

VOLUME 3, NUMBER 2 (2010)

ISSN 2029-0405

http://www.versita.com/science/law/bjlp

Cit.: Baltic Journal of Law \& Politics 3:2 (2010): 40-68

DOI: $10.2478 / \mathrm{v} 10076-010-0010-\mathrm{z}$

\title{
THE EXCEPTIONAL STATE OF THE MEDIA: SOME EXPERIENCES IN POST-SOVIET LITHUANIA
}

\author{
Gintaras Aleknonis \\ Associate Professor; Dr \\ Mykolas Romeris University Faculty of Politics and Management (Lithuania) \\ Contact information \\ Address: Ateities str. 20, LT-08303 Vilnius, Lithuania \\ Phone: (+370 5) 2740611 \\ E-mail address: aleknonis@mruni.eu
}

Received: October 30, 2010; reviews: 2; accepted: December 7, 2010

\begin{abstract}
Theoretical attempts to solve the problem of exception inevitably draw attention to the conflict between freedom and equality, the core values of a democratic society. Granting exclusive rights to one institution or another is justified by the principle of freedom, yet this does not necessarily comply with the idea of equality. Experience shows that it is difficult to avoid exceptions and exceptional rights in the search for consensus in a democracy. Using the popular myth of the fourth estate, media often claims such special rights.

This article examines how over twenty years of independence Lithuania has treated one of the most widely applied privileges of mass media - confidentiality of the source of information. When discussing how in practice Lithuania implements the right to deny false claims, it is assumed that mass media disregards all information accuracy principles and aims to portray itself, at least in its own eyes, as an infallible institution having exclusive rights. The country's weak declarations of interest traditions, which have not yet fully developed in the past fifteen years, only strengthen such mass media attempts.

Exclusiveness is in the nature of the media already, in that it helps to draw the attention of the public and can provide significant economic benefits. On the other hand, a privileged position often damages the media, since the fourth estate is special - its authority should be based not on rights and privileges, but on trust.
\end{abstract}




\section{KEYWORDS}

Exception, media, immunity, confidentiality of the source of information, disclaimer 


\section{INTRODUCTION}

The myth of mass media as the fourth estate is relatively new, yet has strong historical and emotional roots and has quickly gained popularity. It allows the mass media to claim its special position in Lithuania's public life and beyond. What role does exclusiveness play in democracy? In what ways is it expressed in the media and what consequences can it have?

In an attempt to answer these questions, this paper focuses on the media's privilege to protect confidentiality of the source of information. Two examples of mass media exclusiveness are discussed - how Lithuania's media responds to requests to deny erroneous information, and how it implements the legal regulations to declare its public interests.

Exclusive rights, which are so sought by Lithuania's mass media, not only provide considerable benefits, but also raise some concerns, which are discussed in the last part of this article.

\section{THE PURPOSE OF EXCEPTION IN DEMOCRACY AND MASS MEDIA}

The aspiration for exclusiveness is not an exceptional ambition, but rather a phenomenon of everyday social life. The paradox is that anyone seeking exclusiveness would be disappointed if they found out that everyone else who has similar wishes had them fulfilled. Global exclusivity and global exceptions are not possible because then that just becomes a rule. The fewer exceptions there are the more valuable and desired they become. The wish to be in an exceptional state or have exclusive rights could even be seen as a force driving society's progress forward. The desire to do something better and get closer to perfection naturally takes one closer to exceptionality since the result of such efforts is the recognition that one has done something truly outstanding. Such recognition can form the foundation for both irrational envy and productive competition.

Mass media intercepts society's exceptionality and exclusiveness cycle in two ways: (1) by elevating public personalities and creating an "exclusive image" of them and (2) as an institution that desires exclusiveness and successfully uses its privileged speaker status to enforce such pretentions.

A large part of individuals employed in the mass media industry have not fully justified ambitions to call themselves creators or prominent players in the society. Electronic mass media, especially television, unnoticeably overestimates the significance of everyone who appears on the screen. All of a sudden a television show host becomes a welcome guest or a family member who can be trusted with 
the deepest secrets. A television personality's talent spectrum is rather narrow, yet very often the TV show by itself contributes to the popularity. The opportunity to appear in front a thousand or a million viewers creates the perception of exclusiveness. After all, not everyone can appear on the TV screen, so a viewer automatically assigns "celebrity" status to anyone who can. Game and reality shows requiring audience participation further encourage this "star perception" process.

Sometimes the popularity acquired on television accidentally carries over to other areas of society. Politicians often presume that just their appearance on the screen elevates their image. Out of all technologies in the public space, television is the most adept in creating seemingly exceptional personalities; it appears as though with minimal effort television fulfills people's temptations to build a selfimage dominated by the illusion of exclusiveness. The democratic system in the society is unable to suppress or destroy such motives, yet it should be necessary to create some sort of a self-protection system so that distinctiveness acquired through television would not be misused in other areas. Cases when a great entertainer becomes a serious politician are rare. A career change is possible, yet requires serious effort.

Attempts to assign special meaning to institutions should be evaluated slightly differently. What purpose does a special position, distinct institutional rights, and exceptionality granted to an institution have in the political context of a modern democratic society? It must be noted that it is rather difficult to justify the motivation behind exceptions and exclusiveness. John Locke has effectively summarized this by saying, "nor could anyone, by his own authority; avoid the force of the law, when once made; nor by any pretence of superiority plead exemption, thereby to license his own, or the miscarriages of any of his dependents. ${ }^{\prime 1}$ In such a case one would have to talk about certain social exceptions that would contradict the essence of democracy.

At first sight it may seem that exceptions are usually impossible to maintain in a society that emphasizes equality and freedom; however, this is not necessarily true. The denial of exceptions would support the principle of equality, but reckless implementation of such a process and a blind refusal to support any exceptions would neglect the principles of freedom. It becomes obvious that equality and freedom, which are so often seen as forming the same foundations, are not always compatible and can even contradict one another. If the society recognizes a person's right to act freely, then it also grants that person the privilege to express oneself in a way that is most beneficial to themselves and (possibly) the society.

\footnotetext{
${ }^{1}$ John Locke, Second Treatise of Government (The Project Gutenberg EBook), Sect. 94 // http://www.gutenberg.org/files/7370/7370-h/7370-h.htm (accessed October 3, 2010).
} 
This is equivalent to giving the person individual circumstances, so hereby the breaching of the principle of equality is justified. By installing the principles of equality without compromise and by denying exceptions, one runs the risk of creating a Communist system. On the theoretical level, the founders of Communism propagated egalitarian principles, yet the practical implementation of these ideas in the Soviet system created one of the greatest exceptions in the history of humankind. Exceptional rights and special privileges granted to leaders and members of the Communist party laid the founding stones for this social system. From a more abstract point of view - freedom was sacrificed in the name of equality, and as a result both freedom and equality ceased to exist.

Real-world experience also raises the doubt whether it is possible and necessary to avoid exceptions, since democracy relies on the pursuit of consensus and harmony. The adoption of laws is a lengthy and complex negotiation process involving practical interests, ideological positions, and personal opinions. It involves not only legislators, but also numerous other individuals, institutions, and organizations. Sophisticated mechanisms for exerting influence also come into play. Lobbying has become an industry that not only thrives in democratic countries, but also helps to ensure a somewhat transparent impact regarding public interests. Often it is impossible to reach a compromise and balance without sacrificing or giving in to something, which is what creates a space in which democracy lays the foundation for most of its exceptions.

What perhaps helps to justify exceptions and justify exclusive right in a democracy is the hope that such democratic privileges are granted only temporarily, e.g. a leader is elected for a term, after which the individual loses the distinct status. However, in reality, the system in young democracies and in states hiding behind a shield of democracy is less straightforward. Changes in electoral laws allow one to extend a term or to run for the same post for multiple terms in a row. The examples of Belarus and Russia show how easy it is to create the illusion of democracy.

It is significantly more dangerous and more complex to extend special privileges to institutions. For example, the Lithuanian mass media system is relatively stable and its players change positions less frequently than the country's top politicians. The paradox is that it is a tradition to grant exceptional rights to journalists, and yet these rights are still more stable than the privileges given to politicians which are the result of elections and which are constrained by the limited terms of a certain post. 


\section{ATTEMPTS TO CREATE MASS MEDIA IMMUNITY}

Lithuania often takes pride in its laws regulating the information flow in the society. One is often reminded that already back in 1997 experts of the European Council noted that Lithuania's media laws are some of the most democratic ones in Eastern and Central Europe. ${ }^{2}$ However, the practical application of this highly praised legal framework should be evaluated rather carefully.

It would seem that all editions of Lithuanian Laws on Provision of Information to the Public reflect the majority of Lithuania's legislative problems. The legal aspect of the media environment in Lithuania was developed taking into account the liberal corporatism ideas found in Scandinavia, forgetting how these ideas actually naturally evolved over time in e.g. Sweden. It is unlikely that in a newly founded democracy, such as Lithuania, cynical business practices will suddenly unfold and begin to show ethical responsibility.

The situation is more or less the same in the entire region. Karol Jakubowicz and Miklós Sükösd note that

After media laws and institutions had been transplanted from Western to Eastern and Central European contexts, the danger became apparent that democratic laws would not be implemented, or implemented only partially, and democratic institutions would serve as a façade for non-democratic practices. ${ }^{3}$

The democratic and liberal Lithuanian media laws were able to curb the politicians' and state officials' desires to control the mass media, yet did not succeed in helping the media itself to develop a sense of responsibility. From this aspect, the granting of special rights and privileges to institutions informing the society should be evaluated very carefully.

In a democratic country not only the mass media makes use of exclusive rights. Legal immunity - the privilege to be exempt from legal responsibility applies to elected (or those running for office) politicians, lawyers, certain highranked officials, and foreign diplomats. Parliamentary immunity is a kind of safeguard in a democratic system, protecting elected individuals from political plots. Such immunity has double benefits for legal courts - on the one hand it protects the independence of a judge, on the other hand it restricts the government's wishes to exert political means using legal actions. Diplomatic immunity can be justified as the warranty that an "unfriendly" country would not intentionally harm official

\footnotetext{
2 Europos tarybos informacijos biuras (Information Office of the Council of Europe), "Bendroji apžvalga" (An overview) // http://www.etib.lt/?s=apzvalga\&lang=It (accessed March 1, 2009).

3 Karol Jakubowicz and Miklós Sükösd, "Twelve Concepts Regarding Media System Evolution and Democratization in Post-Communist Societies": 22; in: Karol Jakubowicz and Miklós Sükösd, eds., Finding the Right Place on the Map: Central and Eastern European Media Change in a Global Perspective (Bristol: IntellectBooks, 2008).
} 
visitors. Legal immunity is not acquired by chance. It should be seen as kind of public offering, where the society sacrifices a part of justice in exchange for trust. A perfect example of such sacrifice is the immunity from prosecution found in some legal systems, which is the immunity granted to key witnesses in exchange for their testimony.

Legal immunity gives politicians the warranty to act freely and disregard the opinions of governing bodies, yet does not allow them to break laws. In exchange for legal immunity one often has to sacrifice a part of one's privacy. Public figures are bound by law to publically declare their assets, earnings and interests. The public space can also be regarded as the unofficial price paid for legal immunity - in most cases appearances in public become unavoidable. However, it must be mentioned that most politicians like to mingle in the public space anyway, and not only that. Many of them invest a lot of energy and resources to establish a public image for their own benefit - it helps them become more visible and popular. Yet a public figure is not only subject to compliments; such a person has to stand in the center of the media's attention in situations when they do not necessarily want to or when it is not beneficial. Legal immunity can protect an individual from being taken to court or lead to dropped charges, yet such actions will only motivate the mass media to discuss the crimes of the one having legal privileges. Legal immunity offers protection from the law, yet public opinion does not offer any comparable guarantees.

Although immunity from public opinion exists after all, its origins are slightly different and it could be compared to unconditional love and devotion to a certain politician or a public figure. In addition to that, such immunity from public opinion is usually not universal - it applies only to a part of the society and can be rather temporary since it is usually induced by an exceptional event, compassion, etc. The most prominent examples of Lithuanian individuals having such immunity from the public are Vytautas Landsbergis, Algirdas Brazauskas, Rolandas Paksas or Viktor Uspaskich. No matter what these people are accused of - for example, take $\mathrm{V}$. Uspasich's falsified university diploma or his illegal financial transactions - some people will always continue to trust these politicians. However, the neutralization of one of V. Uspaskich's scandals having to do with bribery did require significant efforts and resources. This so-called "envelope scandal" (referring to illegal supplemental salaries handed over to employees in an envelope) took place in 2006 when the "Krekenava" company, directly associated with V. Uspaskich, fired Dalia Budrevičienè, an employee who began to publically talk about these envelopes. "Krekenava" hired the most qualified professionals from the advertising industry and cooperated with Remigijus Vilkaitis, an actor who portrayed V. Uspaskich in the 
the satirical TV show "Dviračio žynios" on the LNK channel. A campaign called "Who will receive Krekenava's envelope?" was launched, during which consumers buy Krekenava's products had the possibility to win a real envelope full of money. Marius Jovaiša, the head of Lithuania's Bureau of Advertisers at that time, called Krekenava's idea the pinnacle of cynicism. ${ }^{4}$ Alas, it must be noted that the campaign was very convincing and suggestive, and the result was unbelievable the image of the "envelope" as a symbol of bribery and dishonesty was destroyed, and the envelope turned into an object of mild mockery. It is also very likely that this campaign only strengthened $V$. Uspaskich's immunity from public opinion. It can be stated that such immunity from public opinion divides the society and breaks the rules of critical thinking. On the other hand, it can be debated whether the existence of collective critical thinking should be debated at all.

In Lithuania, neither journalists nor editors and owners of mass media have legal immunity. Just as any other citizen, they can be prosecuted for withholding taxes, for involvement in traffic accidents and so on. The $25^{\text {th }}$ article of the Lithuanian Constitution talks about the right to have and freely express one's beliefs and reminds us that one should not be obstructed when searching for, receiving, and spreading information and ideas. Of course there is always the risk that the government or a legal body assisting the government will begin to prosecute inconvenient information sources and mass media employees for financial crimes or for disobeying work safety rules. Also, the media always tends to emphasize this risk. From this standpoint the risk to which the mass media is exposed is no different from the risk which political opposition is subject to. So why do mass media employees and owners not get the same legal immunity as political figures?

First of all, mass media personalities are not elected; they build their trust and reputation over time and using hard work. Moreover, granting legal immunity to owners of mass media institutions would open up too many possibilities to misuse these privileges. The mass media, which creates its reputation and builds its authority through the reliability of news messages they expose into the market, always has the possibility to publically complain and spread the news about a certain legal prosecution or reveal details not in favor of certain governing bodies. From this standpoint politicians have significantly fewer possibilities to engage in similar activities.

\footnotetext{
${ }^{4}$ BNS and Irytas.It, "'Vokeliu skandala' Krekenavos agrofirma verčia reklaminiu triuku" (Krekenava agrocompany translates 'The Envelope Scandal' into advertising trick), 2006-04-24 // http://www.Irytas.It/-11458679541145399666-vokeli\%C5\%B3-skandal\%C4\%85-krekenavos-agrofirmaver\%C4\%8Dia-reklaminiu-triuku-papildyta.htm (accessed September 18, 2010).
} 
Since they do not have legal immunity, mass media employees are not automatically obliged to perform certain unpleasant actions that would reveal the nature of their work. Journalists, editors, and owners of mass media institutions are not included in the lists of people who should declare their assets or interests, even though such declarations could be justified by multiple rational arguments. By being aware of their economic interests, the audience would more easily understand sudden and unexpected changes in a publication's content. On the other hand, a public declaration of interests could benefit mass media owners since it would be a kind of antidote to accusations of bias or the use of mass media to defend other commercial interests.

There is a certain balance between legal immunity and the obligation to declare interests. Sometimes publically expressed requirements for journalists and editors to declare their interests are not sufficiently justified. Such a declaration of interests can only be voluntary, yet should be greatly encouraged. If the mass media desires to be not only a hypothetical, but a real fourth estate, it should not only claim benefits, but should also be obliged to respect laws. Since the immunity possessed by the mass media is really not legal but societal immunity, the same logic should apply to the declaration of interests.

Legal immunity is most often (though not necessarily) granted to elected rather than appointed officials. At the end of the term the individual automatically loses the privileges associated with one's duties. Terms in office and their limitations should be regarded as one of the most important safeguards of democracy. There are a number of posts which allow one to remain in office for one or two terms.

In the mass media industry, there are no terms of office like in politics. In the last two decades Lithuania has had four presidents, fifteen different governments, eleven prime ministers, four chairmen of the Constitutional Court. In the same period of time, the editors of "Lietuvos rytas" or "Respublika" did not change even once, and these information sources practically govern the country's information market - both directly and indirectly. When the posts of mass media owners and editors merge, media executives become virtually irreplaceable. In Lithuania, these positions are only formally separated. It would be irrational to demand that a mass media organizations - as private businesses - should limit the number of years an editor or owner can be in office, since the government should not be involved in the private sector. However, mass media is not just a business. It seems that once again here we encounter the media's instinctive desire to reinforce its special privileges: depending on the situation, they can act as private businesses or as institutions performing civil duties. 
This negligence in the public, which allows the media to transform itself and float between the private and public sectors, can also be regarded as a special privilege. In a democratic society, exclusiveness and special rights should be defined and distributed very clearly, and should also possess certain safeguards. It should not come as a surprise that in Lithuania it turned out to be impossible to regulate the mass media privileges lying on the borderline of democratic traditions and legal implications. This presence in the "grey zone" provides the mass media with great benefits.

\section{CONFIDENTIALITY OF THE INFORMATION SOURCE: BETWEEN LAWS AND RESPONSIBILITY}

One should admit that Lithuania did put some effort into granting the mass media certain special rights using legal means. A great example of this is the story surrounding the confidentiality of the information source. In two decades of Lithuania's independence, the four editions of laws regulating the mass media space $^{5}$ always contained articles and rules regarding the confidentiality of the information source.

The confidentiality of the information source is considered to be one of the most important warranties of media freedom and helps ensure the constitutional rights of an individual to possess and freely express one's own beliefs. Journalists are particularly interested in protecting the identity of their information sources, as one can count on the information source's trust only if the sources feel safe even when they disclose information unfavorable to the government or reveal secrets previously unknown to the public. The assumption that the government, politicians, and elite executives tend to hide important information that is unfavourable to them yet essential to the public, has strong reasoning behind it. Regulations are needed for this very same reason - it is necessary to simply yet clearly define the protection of state secrets and information sources. Censorship can turn into a dangerous weapon when dealing with the dispersal of information that is unfavourable or unpleasant to government officials. The natural conflict between state secrecy and the confidentiality of information sources can be solved using

\footnotetext{
${ }^{5}$ Lietuvos tarybu socialistinès respublikos Spaudos ir kitu masinès informacijos priemoniu istatymas (Law on the Press and other Mass Information Providers of the Lithuanian Soviet Socialist Republic), Official Gazette, 1990, no. 7-163.

Lietuvos Respublikos visuomenes informavimo istatymas (Law on Provision of Information to the Public of the Republic of Lithuania), Official Gazette, 1996, no. 71-1706.

Lietuvos Respublikos visuomenés informavimo istatymo pakeitimo istatymas (Revised version of Law on Provision of Information to the Public of the Republic of Lithuania), Official Gazette, 2000, no. 75-2272. Lietuvos Respublikos visuomenes informavimo istatymo pakeitimo istatymas (Revised version of Law on Provision of Information to the Public of the Republic of Lithuania), Official Gazette, 2006, no. 82-3254.
} 
only one approach - the protection of secrets has to be left to the institution, and the protection of the source has to be taken care of by the society.

In Lithuania the right (or privilege) of an information source to remain confidential has undergone an interesting evolution. During the last days of the Soviet regime, on February $9^{\text {th }} 1990$, a Law on the Press and other Mass Information Providers was passed and was in effect during the first years of Lithuania's independence. The law stated that

a mass media information provider is not obliged to disclose it source of information and does not have the right to specify the name and surname of the person providing this information unless this subject has explicitly given his/her consent.

The source of information can only be disclosed to courts and interrogators, and only if it is necessary for the investigation of court cases. ${ }^{6}$

As the Law on Provision of Information to the Public changed in the past two decades, the opinions on the confidentiality of the information sources shifted as well. At least six aspects of such transformations must be mentioned: (1) who receives the privilege; (2) what is the privilege; (3) the duty that results from the privilege and restricts regular operations; (4) conditions allowing one to disobey the imposed limits; (5) the liability resulting from disobedience; (6) conditions for the sake of justice.

(1) How did the concept of the subject receiving the privilege change? In 1990 the talk was only about the so-called mass information "providers". All later legislative changes made this concept more personal, handing the rights and responsibilities over to specific players rather than to an abstract "provider". In 1996 the concept of mass information "provider" changed to the "producer of public information and its owner or journalist"; in the year 2000 this definition was extended with the word "disseminator". In 2006 the "owner" began to be called a "participant". As one can see, the "journalist" remained the most stable part of the definition.

What is the significance of these changes? First of all, they reflect the technical changes in the mass media - the press circulates news articles, yet the most popular channels of distribution involve electronic means such as television, radio, and the Internet. Secondly, the changes recognize the complexity of the information stream's creation, yet acknowledge that the journalist remains not only the most stable, but also the most complex creator in the process. Since the

\footnotetext{
${ }^{6}$ Lietuvos tarybu socialistines respublikos Spaudos ir kitu masinès informacijos priemoniu istatymas (Law on the Press and other Mass Information Providers of the Lithuanian Soviet Socialist Republic), Official Gazette, 1990, no. 7-163, Art. 25.
} 
legislation approves the existence of so many secondary players who may influence the information content, one may raise the doubt if the responsibility is perhaps dispersed too much. The abolition of the "owner" concept raises the most serious concerns, especially since this move occurs at a time when the owners and their interests become increasingly more important. The explanation that the concept of the owner was abolished because more and more often the owner is a corporation or institution rather than a physical person, is rather weak. The concept of the distributor (and the new term "disseminator") is also to be associated with corporations rather than physical individuals. Distributing privileges and responsibilities to physical and legal entities due to the protection of the information source could pose problems in the future and result in a dispersion of responsibility.

(2) The wording of the privilege to maintain the confidentiality of the information source changed only once in the past two decades. In 1990 and in 1996 the legislation stated "shall not have to reveal the source of information", and in 2000 and in 2006 this was already called "shall have the right to maintain the confidentiality of the source of information and not to disclose it". ${ }^{7}$ Liudvika Meškauskaite precisely notes that this is how "duty turned into a right". ${ }^{8}$

Considering the state of journalism at that time, it can be said that the statement of 1990 and 1996, "shall not have to reveal the source of information", played a negative role. Overall, the history of modern journalism in Lithuania could be equated to a process that diminished duties. Till now, people tend to idealize the journalism of the Lithuanian press ban at the end of the nineteenth century, when moral and ideological values had far more importance than the desire to profit from publishing. During the interwar period in Lithuania, political party clashes and the emerging of the yellow press did not manage to deny the previously generally accepted educational objectives of the media. During the Soviet occupation, some people working for political institutions cherished illusions of cultural independence, while others merely blindly followed instructions given to them. The media fought for independence but was morally unprepared for the restoration of independence. On the one hand both journalists and their audience could not believe they finally had the possibility to express themselves freely; on the other hand it was incredibly difficult to resist the temptation to make a lot of money. The new responsibilities, the most important of which was to be a safeguard of democracy, were digested very superficially. The picturesque saying that the media is a watchdog was deformed into the image of an untrained and continuously barking dog that was

\footnotetext{
7 In Lithuanian the wordings of 2000 and 2006 laws are identical, differences are only in official translations into English.

8 Liudvika Meškauskaitè, Žiniasklaidos teisè: visuomenès informavimo teisè: teoriniai ir praktiniai aspektai (Media Law: Law of Public Information: Theoretical and Practical Aspects) (Vilnius: Teisinès informacijos centras, 2004), p. 150.
} 
constantly trying to please everyone. Commercial interests dictated the need for sensationalism, and ruthless competition in the market pushed people into forgetting the methods of how to verify a certain piece of news. The rule of having two independent news sources, which is the foundation of Western media's accuracy, never found its place in Lithuanian mass media.

In this information space, the legislators' urgent call to protect the identity of information sources was interpreted in a quite distorted manner. This is a sad example of the claim that "absoluting the protection of the information source is just as dangerous as a total disregard of such protection. ${ }^{\prime 9}$ The obligation to protect the information source was easily transformed into the right to ignore sources altogether. It seems that the foundation for this tradition of "secret" sources was laid in the last decade of the twentieth century. Honorable media would require that the information source be disclosed only in exceptional cases. In Lithuania, unfortunately, keeping the information source secret is seen as good journalism standard. When elaborating on the public conflict between the right to know and the freedom to inform, it must be mentioned that a similar opposition exists between a journalist's obligation to protect the information source and the reader's right to know where the information came from. Doubts on whether the piece of news is really reliable can be cleared using two methods - the information source can be disclosed (in that case the viewers themselves decide if the source is reliable), or the mass media channel and its employees has to be so valued and trusted that the audience automatically delegates them the privilege to decide on the quality of information sources.

Most readers view the so-called yellow press as a communications game; such mass media sources are known not for their trustworthiness, but rather for their entertainment factor. Often these media sources choose serious political topics to entertain the audience. Readers never find out the source of a political joke; such tasks could only be performed by repressive structures in nondemocratic countries. So the yellow press not only plays a political game, but also thoroughly enjoys its right to keep their information sources confidential. Serious media channels should take this privilege seriously. Protection of the information source can be used not only to hide the source, but to also disguise clever manipulations. Misusing this privilege does not free the mass media; on the contrary, it makes it more vulnerable. One must keep in mind that the obligation to protect the information source can always be used as an excuse for poor professionalism or for the inability to collect and interpret information.

\footnotetext{
${ }^{9}$ Ibid., p. 148.
} 
Just as any other law, the obligation to protect the identity of the information source has to be justified. Therefore the legislative corrections of 2000 and 2006 should be evaluated as positive, yet belated changes. Just one decade managed to harm the mass media and its audience. The media's disrespect for the information source was established, and the audience's right to know the information source was completely disregarded. This is a great example of how the media misused the initial trust of the audience. As history shows, this trust is not boundless or everlasting.

(3) The laws of 1990 and 1996 turned the media's privilege to protect the confidentiality of the information source not just into an obligation, but also established that a journalist "shall have no right to reveal his surname, name and other data". It could even be said that this obligation officially limited the journalists' rights. Naturally, the following question arises - does this not interfere with journalism ethics and with the relationship between the information source and the media professional? Even more importantly, who needed and who benefited from such interference?

The only logical explanation for this journalistic obligation could be attributed to the situation in 1990. The Law on the Press and other Mass Information Providers came into effect in Soviet Lithuania and existed in a period of time when a new state was forming. At that time the method of separating the mass media from the government was understood mostly on a theoretical level, and the concept of human rights was developed using a beginner's mentality. It is always difficult to precisely answer the question whether information creators and protectors are the information owners as well. The issue is also, how long should exceptional rights be valid for and when public interests should be given priority. However, when creating the Lithuanian state and separating the secrets of the Soviet and independent Lithuania, perhaps information sources did in fact need more reliable protection. At the same time, the room for misinformation only grew. As an example, the daily paper "Lietuvos aidas" published a series of narratives called "Voratinkliai" ("Spiderwebs"), which relied only on the duty to protect the information sources. The articles contained facts and fiction alongside one another.

(4) The laws of 1990 and 1996 provided a condition that allowed one to disclose the information source given the source's consent. It is likely that these changes were made in the hope of creating trust between the Lithuanian media and its information sources. Journalists must be ready to honor the confidentiality of their sources, since this is the only way they can ensure they have access to information that is important to the public. At the same time, honorable sources 
agree to come forward in public in extreme situations, e.g. when a court demands so.

(5) The consequences resulting from disobeying the law and disclosing an information source without their consent were only defined in 1996: "Having violated this provision, the public information producer, its owner or journalist shall be liable according to laws, with the exception of cases when the submitted information was incorrect." Although liability is mentioned, the consequences are not specifically defined, allowing a lot of room for disputes between information sources and journalists who have revealed them. The foundation of many such disagreements is often the doubt regarding the correctness of information. In that sense, this part of the legislation acts more like a warning and has not really been implemented in practice. Therefore it is not surprising that it was abolished in later revisions.

(6) The condition for the sake of justice is the clause in the Law on the Press and other Mass Information Providers article 25, published in 1990, which states that the information source can only be disclosed to interrogative institutions or courts, if it is necessary for the investigation of a court case. This condition applied only until the revision of the legislation in 1996, and was then re-inserted into the 2006 Law on Provision of Information to the Public. Today it is worded as follows:

[one can protect the identity of the information source] with the exception of the cases where by a court decision it is necessary to disclose the source of information for vitally important or otherwise significant public reasons, also in order to ensure that the constitutional rights and freedoms of a person are protected and that justice is served. ${ }^{10}$

This was the result of the overdue implementation of the decision of the Lithuanian Constitutional Court from October $23^{\text {rd }}, 2002 .^{11}$

${ }^{10}$ Lietuvos Respublikos visuomenès informavimo istatymo pakeitimo istatymas (Revised version of Law on Provision of Information to the Public of the Republic of Lithuania), Official Gazette, 2006, no. 823254, Art. 8.

11 Lietuvos Respublikos Konstitucinio Teismo nutarimas Dèl Lietuvos Respublikos Visuomenès informavimo istatymo 8 straipsnio ir 14 straipsnio 3 dalies atitikties Lietuvos Respublikos Konstitucijai (Ruling of the Constitutional Court of the Republic of Lithuania On the Correspondence of Article 8 and Article 14 section 3 of Law on Provision of Information to the Public of the Republic of Lithuania to the Constitution of the Republic of Lithuania), Official Gazette, 2002, no. 104-4675. 
THE EVOLUTION OF LAWS REGULATING THE PROVISION OF INFORMATION TO THE PUBLIC IN LITHUANIA. CONFIDENTIALITY OF THE INFORMATION SOURCE

Table 1

\begin{tabular}{|c|c|c|c|c|}
\hline & $\begin{array}{l}\mathbf{1 9 9 0} \text { Law on the } \\
\text { Press and other } \\
\text { Mass Information } \\
\text { Providers } \\
\text { Article } \mathbf{2 5 .} \\
\text { Confidentiality of } \\
\text { Information } \\
\text { Source }\end{array}$ & $\begin{array}{l}\mathbf{1 9 9 6} \text { Law on } \\
\text { Provision of } \\
\text { Information to the } \\
\text { Public } \\
\text { Article } \mathbf{7} \text {. } \\
\text { Confidentiality of } \\
\text { Information } \\
\text { Source }\end{array}$ & $\begin{array}{l}\mathbf{2 0 0 0} \text { Law on } \\
\text { Provision of } \\
\text { Information to the } \\
\text { Public } \\
\text { Article } \mathbf{8} \text {. } \\
\text { Confidentiality of } \\
\text { Information } \\
\text { Source }\end{array}$ & $\begin{array}{l}\mathbf{2 0 0 6} \text { Law on } \\
\text { Provision of } \\
\text { Information to the } \\
\text { Public } \\
\text { Article } \mathbf{8} \text {. } \\
\text { Confidentiality of } \\
\text { Information } \\
\text { Source }\end{array}$ \\
\hline $\begin{array}{l}\text { Who } \\
\text { receives } \\
\text { the } \\
\text { privilege }\end{array}$ & $\begin{array}{l}\text { The provider of } \\
\text { mass information }\end{array}$ & $\begin{array}{l}\text { The producer of } \\
\text { public information } \\
\text { and its owner or } \\
\text { journalist }\end{array}$ & $\begin{array}{l}\text { The producer, } \\
\text { disseminator of } \\
\text { public information } \\
\text { and the owner of } \\
\text { the producer and } \\
\text { (or) disseminator } \\
\text { of information and } \\
\text { journalist }\end{array}$ & $\begin{array}{l}\text { The producer, } \\
\text { disseminator of } \\
\text { public information, } \\
\text { their participants, } \\
\text { and the journalist }\end{array}$ \\
\hline Privilege & $\begin{array}{l}\text { shall not have to } \\
\text { reveal the source of } \\
\text { information }\end{array}$ & $\begin{array}{l}\text { shall not have to } \\
\text { reveal the source of } \\
\text { information }\end{array}$ & $\begin{array}{l}\text { shall have the } \\
\text { right to protect } \\
\text { the source of } \\
\text { information and not } \\
\text { to disclose the } \\
\text { source of } \\
\text { information }\end{array}$ & $\begin{array}{l}\text { shall have the right } \\
\text { to maintain the } \\
\text { confidentiality of } \\
\text { the source of } \\
\text { information and not } \\
\text { to disclose it }\end{array}$ \\
\hline $\begin{array}{l}\text { The duty } \\
\text { that results } \\
\text { from the } \\
\text { privilege }\end{array}$ & $\begin{array}{l}\text { Shall have no right } \\
\text { to reveal the name } \\
\text { and surname of the } \\
\text { person submitting } \\
\text { the information }\end{array}$ & $\begin{array}{l}\text { shall have no right } \\
\text { to reveal his } \\
\text { surname, name and } \\
\text { other data }\end{array}$ & & \\
\hline Conditions & $\begin{array}{l}\text { Without the } \\
\text { consent of the } \\
\text { individual who } \\
\text { submitted the } \\
\text { information }\end{array}$ & $\begin{array}{l}\text { without the consent } \\
\text { of the individual } \\
\text { who submitted this } \\
\text { information }\end{array}$ & & \\
\hline $\begin{array}{l}\text { The liability } \\
\text { resulting } \\
\text { from } \\
\text { disobedience }\end{array}$ & & $\begin{array}{l}\text { Having violated this } \\
\text { provision, the } \\
\text { public information } \\
\text { producer, its owner } \\
\text { or journalist shall } \\
\text { be liable according } \\
\text { to laws, with the } \\
\text { exception of cases } \\
\text { when the submitted } \\
\text { information was } \\
\text { incorrect }\end{array}$ & & \\
\hline $\begin{array}{l}\text { Conditions } \\
\text { for the } \\
\text { sake of } \\
\text { justice }\end{array}$ & $\begin{array}{l}\text { The information } \\
\text { source can only be } \\
\text { disclosed to } \\
\text { interrogative } \\
\text { institutions or } \\
\text { courts, if it is } \\
\text { necessary for the } \\
\text { investigation of a } \\
\text { court case }\end{array}$ & & & $\begin{array}{l}\text { with the exception } \\
\text { of the cases where } \\
\text { by a court decision } \\
\text { it is necessary to } \\
\text { disclose the source } \\
\text { of information for } \\
\text { vitally important or } \\
\text { otherwise } \\
\text { significant public } \\
\text { reasons, also in } \\
\text { order to ensure that } \\
\text { the constitutional } \\
\text { rights and freedoms } \\
\text { of a person are } \\
\text { protected and that } \\
\text { justice is served. }\end{array}$ \\
\hline
\end{tabular}


After reviewing the development of the legislation regulating the provision of information to the Lithuanian public (as overviewed in Table 1), it can be concluded that until 2000 the law increasingly stressed the protection of the information source. In the period 1996-2000 there was even a privilege that was described as a responsibility and there were sanctions (unspecified, however) for disobeying the law and revealing the identity of an information source. Today it is difficult to say whether these privileges were more useful for the media, or for sources that were employed by governmental institutions. Nevertheless it is obvious that there was a certain set of conditions that allowed the journalist to become a hostage of the information source and to be manipulated by it. The media on its own did not understand this danger, so it is fortunate that these loopholes in the legislation were not misused.

\section{RESPONSIBILITY AND THE REQUEST TO DENY ERRONEOUS CLAIMS}

On November $29^{\text {th }}, 2007$, there was a tragic accident on the Ateities Street in Vilnius. A woman on a pedestrian crossing was hit by a vehicle and later passed away. The media, "hungry for blood", instantly sensed an opportunity. In a state of shock, the young driver tried to explain himself rather childishly, "I did not pay attention to the speed limit since I was going to class." The tragedy occurred near the campus of Mykolas Romeris University, known for its law school and often referred to as the institution that prepares lawyers for Lithuanian society. The media did not have to put in a lot of effort to create a scandal, the media headlines spoke for themselves: "Class is more important than life" ("Vilniaus diena"), "A student killed a woman on the way to school" (Irytas.It), "A law student fatally injured a woman" ("Lietuvos rytas"), "A woman on a pedestrian crossing in Vilnius was killed by a future law professional" (alfa.It). 
INTERPRETATIONS OF THE HEADLINE

Table 2

\begin{tabular}{|c|c|c|c|c|c|c|}
\hline Publication & Headline & $\begin{array}{c}\text { Character: } \\
\text { Student }\end{array}$ & $\begin{array}{l}\text { Character: } \\
\text { Law } \\
\text { professional }\end{array}$ & Action & $\begin{array}{c}\text { Contrast } \\
\text { between } \\
\text { news and } \\
\text { death }\end{array}$ & $\begin{array}{c}\text { Contrast } \\
\text { between } \\
\text { the law } \\
\text { and death }\end{array}$ \\
\hline $\begin{array}{l}\text { Vilniaus } \\
\text { diena }\end{array}$ & $\begin{array}{l}\text { Class is more } \\
\text { important } \\
\text { than life }\end{array}$ & Indirectly & No & Neutrally & Yes & No \\
\hline Respublika & $\begin{array}{l}\text { The student } \\
\text { did not reach } \\
\text { class }\end{array}$ & Yes & No & Neutral & No & No \\
\hline L.T. & $\begin{array}{l}\text { The student } \\
\text { took the life of } \\
\text { a pedestrian }\end{array}$ & Yes & No & Direct & No & No \\
\hline $\begin{array}{l}\text { Lietuvos } \\
\text { rytas }\end{array}$ & $\begin{array}{l}\text { A law student } \\
\text { fatally injured } \\
\text { a woman }\end{array}$ & Yes & Yes & Direct & No & No \\
\hline Irytas.It & $\begin{array}{l}\text { A student } \\
\text { killed a } \\
\text { woman on the } \\
\text { way to class }\end{array}$ & Yes & No & Dramatic & Yes & No \\
\hline delfi.It & $\begin{array}{l}\text { A freshman } \\
\text { fatally injured } \\
\text { a woman on } \\
\text { the way to } \\
\text { class }\end{array}$ & Yes & No & Direct & Yes & No \\
\hline balsas.It & $\begin{array}{l}\text { A student } \\
\text { fatally injured } \\
\text { a woman } \\
\text { while rushing } \\
\text { to class }\end{array}$ & Yes & No & Direct & Yes & No \\
\hline alfa.It & $\begin{array}{l}\text { A woman on a } \\
\text { pedestrian } \\
\text { crossing in } \\
\text { Vilnius was } \\
\text { killed by a } \\
\text { future law } \\
\text { professional }\end{array}$ & Indirect & Yes & Direct & No & Yes \\
\hline
\end{tabular}

Table 2 shows how printed and electronic mass media sources interpreted the same event when creating the headlines and emphasizing what the editors felt was most important and worth mentioning. In today's Lithuanian mass media, editors rather than journalists are held responsible for captions, since the editors see the entire context of the publication. Of course, it is too early to draw conclusions about the conscious and subconscious intentions of the editors and the tendencies of the media to become more like the yellow press. However, a superficial investigation of this one news story shows that the website Irytas.It seems to be the most "yellow" publication, while "Vilniaus diena" and "Respublika" make the most professional and neutral appearances. This primary conclusion would probably destroy existing stereotypes. However, one must not forget that when creating a headline, the editor first thinks about ways to attract the reader. How does one draw the audience's attention to an article, by making the headline as dense as possible (Irytas.It emphasized the main character of the story, the student, and dramatized 
the story by accentuating the contrast between news and death), or by underscoring a single aspect of the story ("Vilniaus diena" drew attention to the contrast between news and death, whereas "Respublika" emphasized the student and created a light intrigue - "the student did not reach class").

However, here the interpretation of the event is not the most important aspect. Shortly hereafter it became known that the student who caused the accident was not related to Mykolas Romeris University and that this tie to the educational institution was a mere product of the mass media's imagination (if the university is nearby, the student was probably rushing to a class there). Yet the fact that the student was majoring in law was confirmed.

The Administration of Mykolas Romeris University decided to contact the mass media publications that published incorrect information and ask them to deny their false claims. This action could be interpreted as an experiment or a test to see the effectiveness of the public information legislation's article 44 about the denial of published information. A total of four newspapers ("Lietuvos rytas", "Respublika", "Vilniaus diena", "L.T."), four news portals (delfi.It, Irytas.It, balsas.It, and alfa.It) and two television channels (TV3 and LNK) were contacted regarding this matter:

On November $29^{\text {th }}, 2007$, [the name of the media source] published incorrect information about the educational institution attended by the driver M.L., who caused a fatal traffic accident on November $29^{\text {th }}, 2007$. According to the article's author, the police stated that the woman who was crossing the road on a green light was hit by a M. Romeris University freshman M.L. The italicized phrase "M. Romeris University freshman" is incorrect because the driver of the TOYOTA RAV4, M.L. (born in 1988) is not a student of the Mykolas Romeris University. It follows that the published information misleads the public and simultaneously affects the professional reputation of the Mykolas Romeris University.

Citing the Lithuanian Republic's public information legislation, article 44 paragraph 2, we ask that you publish an article of the same form and extent and deny all false claims. ${ }^{12}$

As a reminder, article 44 paragraph 2 states:

If the false information has been announced through the medium (in the press, on television, radio, etc.), a person about whom such information has been announced, shall have the right to write out refutation which must indicate which published information contradicts reality, when and where it has been announced, which statements of the published information degrade the honour and dignity of a natural person or damage the professional reputation of a legal

\footnotetext{
12 The documents are in Mykolas Romeris University Archive.
} 
person, and to demand that the medium which disseminated such information, would announce such refutation. ${ }^{13}$

Other paragraphs of Article 44 describe a clear procedure on how claims to deny false information should be handled. A disclaimer should be published; this disclaimer should be of the same length and the same form as the falsely published information and must be published within two weeks. If the editorial office does not agree with the complaint, a written response must be mailed back to the physical person or institution within two weeks. After that all further disagreements take place in court.

Mykolas Romeris University received only two responses out of ten: a letter from alfa.It's chief editor Virgis Valentinavičius and TV3's lawyer Zenonas Naus. The web portal alfa.It claimed that it had already corrected the false claims regarding the educational institution of the driver, but that in respect to the complaint received from Mykolas Romeris University they published another disclaimer correcting the erroneous information. TV3's lawyer claimed that the television station would not be able to correct the information due to the fact that Lithuania's civil code defines the obligation to deny false claims only when these false claims are exclusively stated, and Mykolas Romeris University's complaint did not specifically state the claim.

As one can clearly see, the attempt to test the effectiveness of article 44 Refutation of Published Information - showed that the procedure is not very effective. $10 \%$ of the media met all of the requirements, $10 \%$ responded to the claim yet neglected their error by hiding behind formal requirements, and $80 \%$ simply ignored the request to correct erroneous information.

It is highly doubtful that someone will want to repeat such an experiment in the future, therefore the answer to the question of whether such reactions are typical is rather speculative. It would be difficult to get a hold of statistical data about the media's responses to deny erroneous information. It is likely that people and institutions that do not receive responses do not take the issues to courts. Despite the eight answers it failed to receive from the media, Mykolas Romeris University did not contact legal institutions either.

Another interesting fact is that this story is not surprising to a variety of both Lithuanian and international audiences. Most people are not shocked by the media's negligence of the laws, and they are more surprised by the University's resolution to undertake such an experiment and contact the media. Not even one person in

\footnotetext{
13 Lietuvos Respublikos visuomenès informavimo istatymo pakeitimo istatymas (Revised version of Law on Provision of Information to the Public of the Republic of Lithuania), Official Gazette, 2006, no. 823254.
} 
the audience expected for more than a third of the mass media publications to deny their false claims.

The experience of the European Parliament member, Vytautas Landsbergis, also includes an interesting story about the denial of false allegations. The politician describes a case when he was directly associated with criminal activities (the explosion of the Bražuolè bridge in 1996) in a television show:

I wrote a letter regarding this matter, and when the journalist himself [ $\mathrm{E}$. Jakilaitis - G.A.] called me and apologized, saying that he himself was misled by the facts, I suggested he correct his mistake in the same public manner, on the television screen in front of the entire audience. That would have been a mature step, whereas an apology on the phone is rather childish. Too bad I have not yet heard about a mature step from him. ${ }^{14}$

How can the Lithuanian mass media's behaviour and journalists' unwillingness to publically admit and correct their mistakes be explained? Many possible reasons can be found, the key ones being psychological and legal.

(1) The unwillingness to admit mistakes is linked to Soviet journalism traditions. During the Soviet regime media was not allowed to publish mistakes. Any publicly published critical thought had to be approved by the officials beforehand. Critique also had a strict hierarchy - a local newspaper was allowed to criticize an average worker, and a publication of national scope could complain about the chairman of a collective farm, a school principal, or the head of a small company. The Soviet "no mistakes" tradition and the belief that a person publicly criticized in the media is automatically doomed can still be seen in the Lithuanian public space. That is one of the most important factors encouraging the illusion of the "mighty" press and the reason why so many journalists fear to admit mistakes.

(2) The definition of an error in the Lithuanian context must also be noted. It would be pointless to talk about a neutral evaluation of errors. As early in life as in (a Lithuanian) grade school, mistakes are associated with laziness and failure. Errors are humiliating, therefore children fear making them and are just as afraid to admit them. This understanding of a mistake is surely immature, and also distorted. Individuals employed in the media sector cannot be separated from the general problems of the public. Admitting an error would be more painful for a journalist than for the average person because the media has to publically admit its mistakes.

(3) Logically, this understanding of a mistake is connected to the media's desire to escape responsibility, a desire that is becoming more and more difficult to

${ }^{14}$ Vytautas Landsbergis, Žmogaus kokybè. Lietuvos teisètvarkos mislès (Quality of a Man. Puzzles of Lithuanian Law and Order) (Vilnius, 2010), p. 103. 
justify. After all, not all corrections of mistakes in the media are linked to financial or disciplinary penalties; a lot of times disputing an erroneous claim is merely a matter of honor. Nowadays especially digital media can easily correct flaws, since they have the technical advantage over printed media. Most readers would not even notice the corrections made to an online article. The speed at which online publications are updated and at which new articles are issued would partly justify spelling mistakes and minor factual errors. Often websites state when their articles were updated or supplemented. This is a great self-marketing strategy for it demonstrates how quickly a news portal works or that the issues are being tracked and updated rapidly. Websites never state when their articles were corrected, yet that would be a useful feature showing that the editorial office cares about the quality of information.

(4) Legal nihilism is another public disability through which the mass media only highlights its view on admitting and correcting mistakes. Unless compliance with the law is enforced by a rough administrative power, the larger part of society does not believe that laws should be followed. The largest mass media players in the Lithuanian market do not fear court cases because financial penalties are rather small compared to the media profits. Decisions made by the Ethics Commission of Journalists and Publishers are often openly neglected, and the opinion of the Inspector of journalist ethics is ignored. Yet smaller, mostly regional, publications do not feel that safe. Larger fines would put significant strain on their smaller budgets and jeopardize the existence of the publication. However these publications are not the ones creating the trends; the powerful ones dictate the tone.

(5) All of the reasons mentioned above lead the mass media in the same direction - towards the desire to acquire and consolidate exceptional right and a privileged position. It would seem that the Lithuanian mass media is dominated with the perception that exclusive rights rather than the information quality, precision and thoroughness create the publication, radio or television broadcaster's name and lays the foundations for trust. Such a situation reminds one of the Lithuanian corporate sector's wishes to get as many discounts and bargains from the government as possible. That seems to be the most direct way to achieve glory and generate profit. In that sense the media is not an exception, yet it has more opportunities to strive for exceptional rights. The media can always cause a scandal and call every removal of privilege or restriction a fight for the freedom of speech.

(6) The assumptions mentioned in this section, which encourage the Lithuanian media to avoid the public correction of errors and flee from responsibility, apply only in cases when it is supposed that erroneous information is published purely unintentionally. A journalist can be misled by the information 
source (especially when the source has its own agenda and knows that its identity cannot be revealed), the circumstances of the event may be unclear, but the editor's pressure to publish the news article faster than the competition will be immense.

What if erroneous information is published on purpose? In that case the answer is simple - that is not a mistake, it is manipulation. It would be naïve to assume that purposefully published incorrect information would be disputed. Under such circumstances it would be difficult to free oneself from the so-called theories of conspiracy.

The problem is that a short-term outlook prevails in Lithuanian business. For the media as a business, such an understanding is very dangerous. It should not be forgotten that journalists sell not news, but their good name and trust. The audience buys their news because it trusts that the news source picked out what is the most important and current to them. When the media begins to create its own political system, it is inclined to forget that it is merely a tool for manipulating the public rather than the manipulator itself.

\section{TRANSPARENCY AND THE OBLIGATION TO DECLARE INTERESTS}

In 2000 the Law on Provision of Information to the Public, obliging publishing houses to declare who owns what publications, came into effect in Lithuania. This provision was slightly corrected in 2006. The $24^{\text {th }}$ article Data on Participants of Local, Regional, National Newspapers, Magazines and the Information Society Media foresees that

Each year, by March $30^{\text {th }}$, editorial offices of local, regional or national newspapers, magazines and the Information Society media [...] must submit to an institution authorised by the Government in the field of providing information to the public [...] in accordance with the procedure established by the abovementioned institution the data regarding those shareholders or stakeholders of an enterprise who have the right of ownership to or control at least $10 \%$ of all the shares or assets (if the assets are not divided into shares). ${ }^{15}$

Later on this information is publicly issued.

The law also anticipates that politicians should declare their interests in the mass media, and that mass media channels are obliged to announce any support they receive, and the sources of such support. This voluntary declaration of

\footnotetext{
15 Lietuvos Respublikos visuomenés informavimo istatymo pakeitimo istatymas (Revised version of Law on Provision of Information to the Public of the Republic of Lithuania), Official Gazette, 2006, no. 823254.
} 
interests (the law does not outline any sanctions resulting from withholding the information previously mentioned) took the place of the obligation to register a publication, which was outlined in the Law on the Press and other Mass Information Providers in 1990 (Article 8. Registering an information source). Registration used to be a mandatory process which ensured that every publisher declared their activities in advance. It was necessary to submit a form for the governmental institutions and name the publisher, the mass media location and name, the language that would be used to spread information, the intentions of the media, the target area, as well as the publication's extent and periodicity. After submitting the form and paying a fee, the publisher would receive a mass media founding certificate. The publisher could then start the business within a year of obtaining the certificate.

It is obvious that these were only measures applied in the country's transitional period. At the very end of the Soviet era the government did feel the pressure of democracy, yet did not completely "let go" of the media by leaving the registration process intact. Such a decision emphasized the media's special role, yet not by defining privileges, but by enforcing stricter control. It was incredibly difficult to let go of the desire to govern or at least to control printed speech. It is interesting to note that in six years the slightly undemocratic process of registering public media sources was sufficient for the newly founded Lithuanian government.

The Law on Provision of Information to the Public abolished registration and, instead, established rules for the declaration of interests. This was an important democratic move that was supposed to help create an atmosphere of trust between the media and the public. The ability to exert too much influence over information providers was taken away from the government officials. It was possible to misuse the registration process, yet practically there were no cases of misuse - any denial to register a media company could have been made public and such stories would have only harmed politicians. The media's distinctiveness, implemented through this special registration process in the past, was changed to the concept that a selfdignified declaration of interests is a part of exclusivity. Legislative measures helped the media and provided the possibility to exhibit its view on transparency and laws. If publications revealed their interests all the time, it would be seen as superfluous information or even self-marketing. The proposed method was dignified, yet it is a question of whether it worked or not. For almost a decade, the requirement for editors to declare their economic interests was not implemented. The publishers and editors did not want this and the governmental institutions avoided showing initiative, perhaps fearing the media's dissatisfaction. It must also 
be mentioned that there were no specific sanctions or penalties for disobeying the law.

It was only in 2005 that the requirements of the Law on Provision of Information to the Public were implemented for the first time, and the information on editors and distributors of media players became publicly available. This first list was more than modest - only 24 businesses declared their interests. That is not even $3 \%$ of the total, considering that there were more than 758 press publications in the country at that time. However, one of the largest media groups, "Lietuvos rytas", did declare its interests, so judging from a distribution point of view the situation was more optimistic. In 2006, 35 out of 739 ( $4.5 \%)$ publications declared their interests. A large leap occurred in 2007, when 210 out of 783 (almost 27\%) media companies declared their interests. That year the "Respublika" group published their results for the first time. "Lietuvos rytas" and "Respublika" make up a large portion of the "paper press" market. In 2008312 out of 802 (39\%) objects declared their interests; in 2009 it was 474 out of 815 (58\%). In 2010 the number of declarations decreased for the first time down to 461 , yet percentagewise the number remained the same (total - 790; 58\%). ${ }^{16}$

Quantitatively, the situation is improving: $20-30 \%$ of the publications that do not declare their interests are small, and published irregularly or in small numbers. The declaration of interests of some publications such as scientific journals is more of a formality and does not influence the transparency of the information published in the society. It would be great if the Ministry of Culture managed to maintain this achieved declaration level, yet even now problems regarding the quality of declaration arise. The most important web portals (alfa, balsas, bernardinai, delfi) do declare their interests, yet what about personal websites and blogs that target a

16 Lietuvos Respublikos Kultūros ministerijos informacija, Duomenys apie viešosios informacijos rengejus, platintojus ir ju dalyvius (Information of the Ministry of Culture of the Republic of Lithuania, Data about producers, disseminators of public information, their participants), Informaciniai pranešimai (2005, no. 38).

Lietuvos Respublikos Kultūros ministerijos informacija, Duomenys apie viešosios informacijos rengejus, platintojus ir ju dalyvius (Information of the Ministry of Culture of the Republic of Lithuania, Data about producers, disseminators of public information, their participants), Informaciniai pranešimai (2006, no. 37).

Lietuvos Respublikos Kultūros ministerijos informacija, Duomenys apie vietiniu, regioniniu ir nacionaliniu laikraščiu, žurnalu bei informacinès visuomenès informavimo priemoniu dalyvius (Information of the Ministry of Culture of the Republic of Lithuania, Data about participants of local, regional and national newspapers, magazines and public media), Informaciniai pranešimai (2007, no. 34).

Lietuvos Respublikos Kultūros ministerijos informacija, Duomenys apie vietiniu, regioniniu ir nacionaliniu laikraščiu, žurnalu bei informacinès visuomenès informavimo priemoniu dalyvius (Information of the Ministry of Culture of the Republic of Lithuania, Data about participants of local, regional and national newspapers, magazines and public media), Informaciniai pranešimai (2008, no. 35).

Lietuvos Respublikos Kultūros ministerijos informacija, Duomenys apie vietiniu, regioniniu ir nacionaliniu laikraščiu, žurnalu bei informacinès visuomenès informavimo priemoniu dalyvius (Information of the Ministry of Culture of the Republic of Lithuania, Data about participants of local, regional and national newspapers, magazines and public media), Informaciniai pranešimai (2009, no. 36).

Lietuvos Respublikos Kultūros ministerijos informacija, Duomenys apie vietiniu, regioniniu ir nacionaliniu laikraščiu, žurnalu bei informacinès visuomenès informavimo priemoniu dalyvius (Information of the Ministry of Culture of the Republic of Lithuania, Data about participants of local, regional and national newspapers, magazines and public media), Informaciniai pranešimai (2010, no. 36). 
wider audience? If bloggers acquire the right to credit themselves as journalists, they should also publicly disclose information about their websites' sponsors.

The Lithuanian media is still learning to declare its interests, yet it is obvious that this process is already becoming too long. It is important that the Law on Provision of Information to the Public foresees a declaration, yet there is no forced mechanism and there are no sanctions for disobeying the law. This public trust in the media is paying off very slowly, and it is obvious that Lithuania's community of journalists does not value this trust, or the possibility to create a democratic structure themselves. Transparency still remains a value that journalists demand from others, yet the media itself does not think that it should follow the usual requirements expected in a democratic society.

\section{CONCLUSIONS: WHERE THE EXCLUSIVENESS OF MEDIA TAKES US}

It would be too bold to assert that the Lithuanian media has special, exclusive rights. However, journalists try to take the most out of the privileges they do receive. Overall, the exclusiveness corresponds to the nature of the media since media tends to draw attention to itself. The status of exclusiveness is usually a benefit for the mass media, because in this way journalists raise their own value and make their media source more reliable both within the mass media community and also in the society. Special privileges can also lead to significant economic advantages.

Nevertheless, a privileged position can also harm the mass media. The paradox is that exclusiveness both weakens and strengthens the myth of the fourth estate. The myth is strengthened since the concepts of government and privileges are often inseparable. Yet it should not be forgotten that the fourth estate is special and its authority should be based not on laws but on trust - trust that is expressed not during elections, but through daily activities such as making the decision to purchase a newspaper, turning on the television or switching on the radio. Legally established privileges for journalists weaken the authority of the media. However, since the media rules the public space, this weakening remains more on the theoretical level.

As the examples discussed in this article (the Lithuanian media's unwillingness to dispute incorrect information, the decade-long learning to obey the law and publicly declare interests) clearly demonstrate that it will be difficult to curb privileges that were granted to the media using legal means. To the public, the mass media portrays any restriction of its privileges as an attempt to suppress the freedom of speech. 


\section{BIBLIOGRAPHY}

1. BNS, Irytas.It. "'Vokeliu skandala' Krekenavos agrofirma verčia reklaminiu triuku" (Krekenava agro-company translates "The Envelope Scandal" into advertising trick). 2006-04-24 //

http://www.Irytas.It/-11458679541145399666-vokeli\%C5\%B3-

skandal\%C4\%85-krekenavos-agrofirma-ver\%C4\%8Dia-reklaminiu-triukupapildyta.htm (accessed September 18, 2010).

2. Europos tarybos informacijos biuras (Information Office of the Council of Europe). "Bendroji apžvalga" (An overview) // http://www.etib.It/?s=apzvalga\&lang=lt (accessed March 1, 2009).

3. Jakubowicz, Karol, and Miklós Sükösd. "Twelve Concepts Regarding Media System Evolution and Democratization in Post-Communist Societies": 9-40. In: Karol Jakubowicz and Miklós Sükösd, eds. Finding the Right Place on the Map: Central and Eastern European Media Change in a Global Perspective. Bristol: IntellectBooks, 2008.

4. Landsbergis, Vytautas. Žmogaus kokybè. Lietuvos teisètvarkos mislès (Quality of a Man. Puzzles of Lithuanian Law and Order). Vilnius, 2010.

5. Lietuvos Respublikos Konstitucinio Teismo nutarimas Dèl Lietuvos Respublikos Visuomenès informavimo jstatymo 8 straipsnio ir 14 straipsnio 3 dalies atitikties Lietuvos Respublikos Konstitucijai (Ruling of the Constitutional Court of the Republic of Lithuania On the Correspondence of Article 8 and Article 14 section 3 of Law on Provision of Information to the Public of the Republic of Lithuania to the Constitution of the Republic of Lithuania). Official Gazette, 2002, no. 104-4675.

6. Lietuvos Respublikos Kultūros ministerijos informacija, Duomenys apie viešosios informacijos rengejus, platintojus ir ju dalyvius (Information of the Ministry of Culture of the Republic of Lithuania, Data about producers, disseminators of public information, their participants). Informaciniai pranešimai, 2005, no. 38: 9-10.

7. Lietuvos Respublikos Kultūros ministerijos informacija, Duomenys apie viešosios informacijos rengejus, platintojus ir ju dalyvius (Information of the Ministry of Culture of the Republic of Lithuania, Data about producers, disseminators of public information, their participants). Informaciniai pranešimai, 2006, no. 37: 11-13.

8. Lietuvos Respublikos Kultūros ministerijos informacija, Duomenys apie vietiniu, regioniniu ir nacionaliniu laikraščiu, žurnalu bei informacinès visuomenès informavimo priemoniu dalyvius (Information of the Ministry of 
Culture of the Republic of Lithuania, Data about participants of local, regional and national newspapers, magazines and public media). Informaciniai pranešimai, 2007, no. 34: 26-37.

9. Lietuvos Respublikos Kultūros ministerijos informacija, Duomenys apie vietiniu, regioniniu ir nacionaliniu laikraščiu, žurnalu bei informacinès visuomenes informavimo priemoniu dalyvius (Information of the Ministry of Culture of the Republic of Lithuania, Data about participants of local, regional and national newspapers, magazines and public media). Informaciniai pranešimai, 2008, no. 35: 25-41.

10. Lietuvos Respublikos Kultūros ministerijos informacija, Duomenys apie vietiniu, regioniniu ir nacionaliniu laikraščiu, žurnalu bei informacinès visuomenès informavimo priemoniu dalyvius (Information of the Ministry of Culture of the Republic of Lithuania, Data about participants of local, regional and national newspapers, magazines and public media). Informaciniai pranešimai, 2009, no. 36: 22-44.

11. Lietuvos Respublikos Kultūros ministerijos informacija, Duomenys apie vietiniu, regioniniu ir nacionaliniu laikraščiu, žurnalu bei informacinès visuomenes informavimo priemoniu dalyvius (Information of the Ministry of Culture of the Republic of Lithuania, Data about participants of local, regional and national newspapers, magazines and public media). Informaciniai pranešimai, 2010, no. 36: 19-36.

12. Lietuvos Respublikos visuomenes informavimo istatymas (Law on Provision of Information to the Public of the Republic of Lithuania). Official Gazette, 1996, no. 71-1706.

13. Lietuvos Respublikos visuomenès informavimo istatymo pakeitimo istatymas (Revised version of Law on Provision of Information to the Public of the Republic of Lithuania). Official Gazette, 2000, no. 75-2272.

14. Lietuvos Respublikos visuomenés informavimo istatymo pakeitimo istatymas (Revised version of Law on Provision of Information to the Public of the Republic of Lithuania). Official Gazette, 2006, no. 82-3254.

15. Lietuvos tarybu socialistinès respublikos Spaudos ir kitu masinés informacijos priemoniu istatymas (Law on the Press and other Mass Information Providers of the Lithuanian Soviet Socialist Republic). Official Gazette, 1990, no. 7-163.

16. Locke, John. Second Treatise of Government. The Project Gutenberg EBook // http://www.gutenberg.org/files/7370/7370-h/7370-h.htm (accessed October 3, 2010)

17. Meškauskaitè, Liudvika. Žiniasklaidos teisè: visuomenès informavimo teisè: teoriniai ir praktiniai aspektai (Media Law: Law of Public Information: 
Theoretical and Practical Aspects). Vilnius: Teisinès informacijos centras, 2004. 